\title{
The California Alien Land Law and the Fourteenth Amendment
}

\section{Edwin E. Ferguson*}

THE PAST few years have seen a surge of. activity by California law-enforcement officers, aided by new state legislation and augmented appropriations, in the investigation of possible violations of the alien land law and the imstitution of escheat proceedings. By the summer of 1945 approximately thirty escheat actions had been begun, judgments in favor of the state had been entered in four of them, and out-of-court settlenients of $\$ 100,000$ and $\$ 25,000$, respectively, had been effected in two others. ${ }^{1}$ By the spring of 1946 some fifty actions were pending. All of these suits involved agricultural lands and were directed against persons of Japanese ancestry. Additional suits have since been filed. ${ }^{3}$

The alien land law, first enacted in 1913, denies to aliens ineligible for citizenship the right to own, lease, or otherwise enjoy land, except to the extent provided by treaty. ${ }^{4}$ Despite the manifest discrimination against one class of aliens and the deprivation of property rights involved, the United States Suprene Court in 1923 upheld the law, concluding that it did not violate the equal protection and due process guaranties of the Fourteenth Amendment. ${ }^{5}$ The new wave of escheat actions has resulted in a new test of the law. Late in 1946, in an appeal from a judgment of escheat which again raised the equal protection and due process issues, the California supreme court reaffirmed the constitutionality of the law in People v. Oyama, ${ }^{6}$ relying upon the rationale provided by the 1923 decisions.

This article, it is believed, will demonstrate that the alien land law was enacted and has been enforced solely as a discriminatory

*B.S. in Ed. 1931, LI.B. 1934, Drake University; J.S.D. 1937, Yale University. Assistant General Counsel, Federal Public Housing Authority; formerly Solicitor, War Relocation Authority; member of the Iowa Bar. The opinions expressed in this article are those of the author and do not necessarily reflect the official view of any organization with which he has been or is now associated.

\footnotetext{
1 Business Week, Aug. 4, 1945, at 50.

2 Pacific Citizen, Feb. 2, 1946, at 1.

3 Pacific Citizen, Nov. 9, 1946, at 2.

$\$$ Cal. Stats. 1913, p. 206; ibid. 1921, p. laxiii.

5 Porterfield v. Webb (1923) 263 U.S. 225.

${ }^{B}$ (1946) 29 A. C. 157,173 P. (2d) 794.
} 
law directed against the Japanese; that the rationale supplied by the United States Supreme Court in support of its constitutionality, and followed in the Oyama case, is premised upon untenable assumptions; and that the law serves no substantial public purpose. If this be true, the California court should have given the law the "rigid scrutiny" which the United States Supreme Court recently said should be given all legislation based on racial differences, ${ }^{7}$ and declared it unconstitutional. 8

\section{GENESIS AND HISTORY OF THE LAW}

Historians say that the purpose of the California alien land law was to discourage further immigration of Japanese aliens to California and to call to the attention of Congress and the rest of the country the desire of California that the "Japanese menace" be crushed." That conclusion is amply supported by studies of the growth and strategy of anti-Oriental agitation in California.

The Japanese immigrants to the mainland of the United States were the legatees of a strong prejudice against Orientals which was originally directed toward the Chinese, who preceded the Japanese by almost fifty years. This prejudice began to build up with the largescale immigration of the Chinese initiated by the gold-rush. ${ }^{10}$ Those who led the campaign were labor unions, who feared the economic competition of the Chinese, and politicians, who sought the support of labor. In September, 1877, the San Francisco Trade and Labor Union broke with existing political parties to enter politics as the Working Men's Party of California. Of the 152 members of the convention to draw up a new state constitution in 1879 , fifty-one were members of the working men's party. ${ }^{11}$ Article XIX of this constitution was devoted exclusively to the expression of a policy intended to discourage residence in the state by Chinese. ${ }^{12}$ Numerous laws and

7 Korematsu v. United States (1944) 323 U. S. 214.

8 Cf. Barnette v. West Virginia State Board of Education (S.D.W. Va. 1942) 47 Fed. Supp. 251, declaring a flag-salute regulation unconstitutional despite a prior Supreme Court decision holding a similar regulation valid.

9 Strong, The Second-generation Japanese Problem (1934) 46; H. R. Rep. No. 2124, 77th Cong. 2d Sess. (1942) at 85; see also, Rep. Cal. State Bd. Control, California and the Oriental (1920) at 11.

10 Between 1850 and 1852 the number of Chinese in California increased from 1,000 to 20,000. Hunt and Sánchez, A Short Fltstory of Californta (1929) 529. In 1882 there were 132,300 Chinese in the state, the largest number ever recorded. See Cooltoge, Cetinese Imomigratton (1909) 498.

11 HuNs and SÁNCHEZ, op. cit. supra note 10, at 548.

12 Section 4 of article XIX of the 1879 constitution opens with this language: "The presence of foreigners ineligible to become citizens of the United States is de- 
municipal ordinances aimed at the Chinese were enacted shortly before and after the adoption of the constitution of 1879 . They were obviously unconstitutional but they dramatized for the whole country the dissatisfaction of the Californian with his Chinese neighbor. ${ }^{13}$ Popular feeling was fanned to such a pitch that many acts of violence against individual Chinese occurred. ${ }^{14}$ Primarily as a result of this agitation, the first Chinese exclusion act became law in $1882 .{ }^{15}$ Under a later amendment, Chinese laborers departing from the United States for China for visits were denied reentry. ${ }^{16}$ The Chinese population in the state began immediately to decline. From 132,300 Chinese in 1882 , it dropped to 107,488 in $1890 ; 89,963$ in 1900; 71,531 in 1910; and 61,639 in 1920 . With this decline in number, the agitation against the Chinese subsided. ${ }^{17}$

The pattern for dealing with the Chinese-local opposition by apparently competing economic groups, physical violence highly publicized, capitalization on racial and color prejudices by politicians, enactment of laws constitutional or otherwise to direct national attention to the "problem", followed by national legislation to deny admittance to the "undesirable" aliens-was destined to be followed in dealing with the Japanese.

The year 1900 saw the real beginning of anti-Japanese agitation..$^{18}$ In 1900, 12,628 Japanese entered the country. ${ }^{19}$ Through the annexa-

clared to be dangerous to the well-being of the State, and the Legislature shall discourage their immigration by all the means within its power."

13 E.g., Chy Lung v. Freeman (1875) 92 U.S. 275; Yick Wo v. Hopkins (1885) 118 U.S. 356; In re Ah Fong (C.C.D. Cal. 1874) 1 Fed. Cas. 213; Ho Ah Kow v. Nunan (C.C.D. Cal. 1879) 12 Fed. Cas. 252; In re Ah Chong (C.C.D.Cal. 1880) 2 Fed. 733; In re Parrott (C.C.D. Cal. 1880) 1 Fed. 481; In re Quong Woo (C.C.D.Cal. 1882) 13 Fed. 229; In re Tie Loy (C.C.D. Cal. 1886) 26 Fed. 611; Ling Sing v. Washburn (1862) 20 Cal. 534.

14 Rep. Cal. State Bd. Control, op. cit. supra note 9, at 7.

1522 Srar. (1882) 58. This statute was enacted as a temporary measure but it later became permanent legislation. 23 Sxar. (1884) 115; 27 Stat. (1892) 25; 32 Star. (1902) $176 ; 33$ STAT. (1904) 428; 8 U.S.C. (1940) 263. The Chinese exclusion laws were repealed during World War $\Pi$, however, and Chinese are now admitted on a quota basis. 57 STAT. (1943) 600.

1623 Stat. (1884) 115.

17 ICHIHASH, JAPANESE IN THE UNITED STATES (1932) 161.

18 The failure of attempts to arouse any measurable antipathy prior to 1900 was due to the comparatively small number of Japanese immigrants. In 1890 there were only 2,039 Japanese in California. ICHIHASHI, op. cit. supra note 17, at 53. Annual Japanese immigration first exceeded 1,000 in 1891 , and had risen to only 2,844 in 1899. REP. Comm'R Isaric. 1900, at 35. During this period, however, there were isolated labor outbreaks against Japanese. ICHIHASHI, op. cit. supra note 17, at 229.

10 Rep. CoMm'r Isang. 1900, at 10. 
tion of Hawaii in 1898, all indentured labor contracts in the Islands had been automatically abrogated, thus liberating thousands of Asiatic peons. ${ }^{20}$ Many of them came to the mainland. The influx directly froin Japan was accelerated by steamship lines and emigration companies. ${ }^{21}$ This mcreased migration gave rise to the first wave of resentment by the white workers of the state, an attitude which was adroitly exploited by the political agitators anxious to secure the labor vote.

On May 7, 1900, a mass meeting in San Francisco, held to discuss the Bubonic Plague, adopted a resolution that the Chinese exclusion act be extended to apply to the Japanese. ${ }^{22}$ In response to a recommendation by the governor in January, 1901, the California legislature adopted its first resolution urging Congress to protect American labor by restricting Japanese immigration. ${ }^{23}$ In November, 1904, the American Federation of Labor at an annual convention in San Francisco adopted a resolution to exclude Japanese and Koreans as well as Chinese laborers. The San Francisco Chronicle followed with a series of inflammatory articles against the Japanese in California which was highly effective in whipping up popular feeling against them..$^{2 k}$ In March, 1905, the California legislature passed a second resolution demanding action to limit the immigration of Japanese laborers. ${ }^{25}$

In May, 1905, the Asiatic Exclusion League, originally the Japanese and Korean Exclusion League, was organized in San Francisco. The avowed purpose of the league was to prevent or minimize the immigration of Asiatics. This organization favored the segregation of Japanese in separate schools and a boycott against Japanese workers and businessmen. It claimed a membership in California alone of 110,000 by February, 1908. Of the 238 affiliated bodies composing the league, 202 were labor umons; the rest were fraternal, civic, benevolent, political, and military societies. ${ }^{26}$

20 Pajus, The Real Japanese Caltfornta (1937) 5.

21 IcrLHASHr, op. cit. supra note 17, at 88. The number of Japanese in this country swelled from 24,326 in 1900 to 72,157 in 1910. See 15th Census of the United States: 1930, Population, Vol. II, p. 32. Most of these Japanese settled in Cahifornia.

22 Buell, The Development of the Anti-Japanese Agitation in the United States (1922) 37 Por. Sct. Q. 605, 608.

23 ICERHASHI, op. cit. supra note 17, at 231.

24 McWnLIAMS, Prejudice (1944) 17.

25 ICHIHASHI, op. cit. supra note 17 , at 250 .

2625 REP. INDMTG. CoMm. (1911) 169 ; Buell, op. cit. supra note 22 , at 617 . The Asiatic Exclusion League was beheved to have received contributions from the IIawaiian planters' associations to assist in agitation which would discourage Japanese in Hawaii 
In October, 1906, the San Francisco Board of Education by resolution ordered the segregation of Japanese pupils in the public schools. Protests were immediately made to the Japanese government and its intercession caused President Theodore Roosevelt to send Secretary Metcalf to investigate. In his message to Congress of December 4, 1906, the President denounced the segregation measure as "wicked absurdity". A survey showed that there were only 93 Japanese pupils in a total school population of 29,000. In January, 1907, President Roosevelt summoned the San Francisco School Board to Washington and in return for his agreement to end Japanese immigration, the Board agreed to rescind the resolution. ${ }^{27}$ Ensuing negotiations with the Japanese government resulted in the so-called gentlemen's agreement, announced in July, 1908, under which the Japanese government agreed to limit passports for the United States to nonlaborers or to such laborers as had already established a domicile $m$ this country, and to persons who were seeking to join a parent, wife or child resident in the United States, or who intended to assume control of an already acquired farming enterprise. ${ }^{28}$

These developinents, however, did not appease the agitators. At the California legislative session of 1909 , no less than seventeen antiJapanese bills were introduced. The intervention of the President defeated a school segregation bill. The first alien land bill directed at the Japanese failed when at the President's suggestion it was amended to apply to all aliens. ${ }^{29}$ The only anti-Japanese ineasures which became law were a resolution favoring exclusion, which was sent to both houses of Congress without results, and an appropriation for gathering and publishing statistics regarding Japanese in the state. ${ }^{30}$

In the California election campaign of 1910 the Republican, Democratic and Socialist parties urged exclusion. ${ }^{31}$ An exhaustive report completed by the state commissioner of labor in 1910, which

from seeking better economic opportunities on the mainland. Report, Royal Commission Appointed to Enquire into the Methods by which Oriental Laborers have been Induced to Come to Canada (1907) 41. See also, ICHIEASHI, op. cit. supra note 17, at 249.

27 STRONG, op. cit. supra note 9, at 41; IcHIHASHr, op. cit. supra note 17, at 244. "Although various explanations of this resolution were given at the time, the real reason was to start the process of discrimination which would eventually lead to the enactment of an exclusion law." Treat, Japan and the UnIted States (1921) 254. President Roosevelt's weak stand was undoubtedly due to alignment of the solid south with California on the racial issue involved. McWIIIIAXIS, PREJUDICE (1944) 29-34.

25 REP. Coslar'R Inang. 1908, at 221; Buell, op. cit. supra note 22, at 634 .

29 IcrmaASHI, op. cit. supra note 17 , at 250 .

3025 Rep. Inaric. Cònar. (1911) 171; ICrnaAser, op. cit. supra note 17, at 251.

3125 Rep. Iararig. CoMar. (1911) 117; IcriHASBn, op. cit. supra note 17, at 252. 
concluded that the continued importation of Japanese labor was necessary for the development of California agriculture, was disapproved and suppressed by the California Senate. ${ }^{32}$ The following year that body memorialized the President and Senate of the United States to disapprove the 1911 treaty with Japan, protesting the lack of an exclusion clause. ${ }^{33}$

In the 1911 California legislative session a bill prohibiting land ownership by aliens not eligible for citizenship passed the Senate by a vote of twenty-nine to three but died in committee in the Assembly. Presidential intervention once more was instrumental in killing the bill. ${ }^{34}$ Opposition also came from the Panama Pacific Exposition Company and its supporters, who feared the effect of the measure upon Japan's participation, and possibly that of other countries as well, in the forthcoming exposition at San Francisco. ${ }^{35}$

By 1913 the political situation was ripe for the passage of an antiJapanese land law. The state administration in California remained Progressive Republican while the national administration became Democratic and exercised less influence over the state legislature. The Exposition had progressed to the point where the appeal for its success was no longer sufficiently effective. Opposition to the bill came only from a few relatively ineffective groups. ${ }^{36}$

The choice presented to the legislature was the enactment of a law applicable only to aliens ineligible for citizenship, or of a law applicable to all aliens. The latter would have affected large European holdings and strong pressure against it was brought by the San Francisco real estate board, chanibers of commerce, boards of trade, merchants associations, and foreign oil and copper syndicates. ${ }^{37}$ At this juncture Secretary of State Bryan visited California "for the purpose of counseling with the members of the Legislature and co-operating with them in framing a law which would meet the views of the People of the State and yet leave untouched the international obligations of the United States" (i.e., conform to the 1911 treaty with Japan).$^{38}$

32 ICHIEASH, op. cil. supra note 17, at 253; CAL. SenATE J. (1910) 39.

33 ICRIEASEI, op. cit. supra note 17 , at 255 .

34 Ibid. at 264.

35 Hichborn, Story of the Caltrornia Legislature of 1911 (1911) 342 ; Millis, The Jafanese Problemc in the Untted States (1915) 200.

36 Ibid. at 204; ICHTHASHI, op. cit. supra note 17, at 265.

${ }^{37}$ Mruris, op. cit. supra note 35, at 202; Buell, The Development of Anti-Japanese Agitation in the United States II (1923) 38 PoL. SCI. Q. 57, 62.

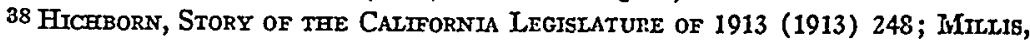
op. cit. supra note 35 , at 206. 
Shortly after his departure, a bill was passed by overwhelming majorities in both houses and became law in May, 1913. The law prohibited aliens ineligible for citizenship (hence, Japanese aliens) ${ }^{39}$ from acquiring, possessing, enjoying, or transferring real property or any interest therein except to the extent prescribed by existing treaties. A similar prohibition applied to corporations a majority of whose members were ineligible aliens or a majority of whose issued capital stock was owned by such aliens. An exception was made permitting the lease of land for agricultural purposes for a ternn not exceeding three years; land already owned by ineligible aliens, or acquired in satisfaction of existing liens, might be retained. Property acquired or held in violation of the law was subject to escheat by the state, acting through the attorney general, title passing upon entry of final judgment. ${ }^{ \pm 0}$

Since the treaty with Japan in 1911 specifically protected the right of Japanese nationals to lease land for residential and commercial purposes and to own residential and business property in the United States, ${ }^{41}$ the new law was effective only to proscribe the ownership or long-term lease of agricultural land. However, a large number of the Japanese were engaged in agriculture. ${ }^{42}$ By 1909 they were a dominant element in the farm labor supply..$^{43}$ Like other immigrant groups, they had begun seeking the stability and increased income opportunities of land tenure. Japanese-controlled farms in California had increased from 29 units (4,698 acres) in $1900^{44}$ to 1,816 units $(99,254$ acres) in 1910.45 These facts largely explain the concerted and finally successful efforts of the anti-Japanese groups, balked in their attempts to obtain federal action completely barring further Japanese immigration, to secure passage of the alien land law, even though it would prohibit only acquisition of agricultural lands in the case of

39 The right to naturalization was at that time restricted to white persons and persons of African nativity or descent, although it has since been extended to descendants of races indigenous to the western hemisphere, persons of Chinese nativity or descent, Filipinos, and persons of races indigenous to India. See 8 U. S. C.A. $\$ 703 ;$ Pub. L. No. 483 , 79th Cong. 2d Sess. (July 2, 1946.) Japanese aliens are not "white persons" within this statute. Ozawa v. United States (1922) 260 U.S. 178; In re Saito (C. C. D. Mass. 1894) 62 Fed. 126; In re Yainashita (1902) 30 Wash. 234, 70 Pac. 482.

40 Cal. Stats. 1913, p. 206.

4137 Stat. (1911) 1504.

42 An estimated 30,000 Japanese were employed in California agriculture in 1909, of whom about 24,000 were farm laborers. 23 REP. IMrMIG. Comm. (1911) 33, 61.

43 MuLIs, op. cit. supra note 35, at 105.

41 Ibid. at 137.

45 U. S. Census Bureau Bull. No. 127 (1914). 
the Japanese. It was reasoned that such legislation would largely discourage their further inflow and encourage those already here to return to their homeland. ${ }^{48}$

The period immediately following the enactment of the alien land law was relatively an era of good will toward Japanese aliens. On January 22, 1915, a bill was introduced in the Assembly proposing to delete the clauses in the alien land law which allowed aliens to lease farm lands for a period of three years, but it met opposition from the press and political leaders of the state. ${ }^{4 \pi}$ With the war came a demand in rural districts for labor to meet the void caused by the departure of white farm laborers to industrial centers. Japanese farmers, as laborers and tenants, were again in good repute and they took advantage of their opportunities. ${ }^{48}$ Two factors, however, bode for further trouble. Despite the alien land law, Japanese immigration continued almost unabated and Japanese farming activities in California continued to expand. From 1913 to 1920, the year in which the initiative alien land law was adopted, 77,936 Japanese aliens came to this country; 59,098 departed, leaving a net gain of $18,838 . .^{10}$ The gentlemen's agreement apparently was not observed too closely during these years, although many of those admitted, such as wives and children, were not subject to its provisions. ${ }^{.0}$ The increase in the number of women was coincident with and reflected the advance in status of the Japanese from farm laborers to farm operators. In 1919, the state board of control reported that the Japanese in California owned or had contracted to buy 74,769 acres of agricultural land and leased or held by contract 383,287 acres. $^{51}$

46 U. S. Webb, co-author of the 1913 law, frankly stated in a speech before the San Francisco Commonwealth Club on August 13, 1913: "The fundamental basis of all legislation upon this subject, State and Federal, has been, and is, race undesirability . . . . It [the 1913 law] seeks to limit their presence by curtailing their privileges which they may enjoy here; for they will not come in large numbers and long abide with us if they may not acquire land." IcHIEASHI, op. cit. supra note 17 , at 275 . See also, PAJUs, op. cit. supra note 20 , at 71 .

$4 \mathbf{r}$ Ibid. at $73-78$.

18 Ibid. at 32, 78; Dearborn Independent, Sept. 11, 1920, at 8 (Wallace, Waving the Yellow Flag in California).

19 See IchHHASHI, op. cit. supra note 17 , at 62 .

50 The earher immigrants were almost exclusively males. During this period many aliens brought in their wives and children. See CaIIFornia Fardrers Co-operattve Asso-

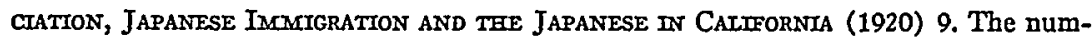
ber of males per 100 females among the Japanese dechined from 694.1 in 1910 to 189.8 in 1920. 14th Census of the United States: 1920, Population, Vol. III, p. 15.

51 Rep. Cal. State Bd. Control, op. cit. supra note 9, at 47 . These figures indicate that the alien land law was not enforced at all rigorously during this period. It is also 
Hostilities of World War I had been ended only a short time when agitation against the Japanese in California was renewed. The increase in immigration during the war and the increase in land ownership and control furnished effective ammunition. Returning soldiers and disnissed war workers saw in the Japanese barriers to their reestablishment as farmers and to their obtaining jobs. Politicians manipulated this potential hostility to their own advantage. ${ }^{52}$

At the governor's request the state board of control issued a report in 1919 on the leasing of land in California to aliens ineligible for citizenship. The report dealt only with Japanese, Chinese and Hindus. It dwelt only briefly upon the Hindus, who were negligible in number, and the Chinese, who (the report concluded) were generally engaged in small commercial enterprises and could not be considered a menace because of the Chinese exclusion acts. Nearly the entire report was given over to the Japanese problem-population, birth rate, land ownership and control, financing, labor, the fishing industry, immigration, etc. Aliens and citizens were lumped together in figures on population and land ownership, and much emphasis was placed on the allegedly high birth rate of the Japanese. The governor transmitted the report to the secretary of state under a letter urging control of Japanese immigration. ${ }^{53}$ But any anti-Japanese legislation at that time was blocked by a request that such legislation be delayed because of the unfortunate effect it would have upon negotiations for a peace treaty. ${ }^{54}$ However, in the off-year of the legislature, and during the election year, 1920, an initiative measure went on the ballot. The chief pressure group supporting the measure was the Joint Immigration Committee, composed of members of the old Exclusion League, the American Legion of California, the State Federation of Labor, the Native Sons of the Golden West, the California State

true, however, that the Japanese were by various devices able to circumvent the law, as by purchase in the name of their minor citizen children, trust arrangements, and by use of dummy corporations nominally controlled by citizens. Ibid. at 12, 69; PAJUs, op. cit. suspra note 20 , at 72 ; Buell, op. cit. supra note 37 , at 66 .

52 The governor of California in a speech on January 21, 1920, said: "In my opinion the present agitation in California was inspired by candidacy for office. It is true that many worthy citizens have now allied themselves with it for laudable purposes. The fact remains, however, that the dominant factors in the inovement are actuated by their desires for political preferment." Kawakana, The Rear Japanese Question (1921) 84; see Treat, op. cit. supra note 27, at 261.

63 Rep. Cal. State Bd. Control, loc. cit. supra note 9.

64 Ibid. at 12. 
Grange, and other individuals who had long been active in "saving" California fron the "yellow peril".

The mitiative measure continued in effect the prohibitions of the 1913 law, and deleted the provision authorizing leases of agricultural land for not over three years. In order to plug loopholes in the 1913 law, ${ }^{56}$ the measure forbade membership or acquisition of any stock by ineligible aliens in corporations authorized to acquire agricultural land, prohibited such aliens from serving as guardians of estates which they could not properly own or enjoy themselves, ${ }^{57}$ required yearly reports from persons acting as guardians, trustees, or agents of ineligible aliens or their minor children, and established a presumption of mtent to avoid escheat where a conveyance was made to an eligible person and the consideration was paid by an ineligible alien. Conspiracy to violate the law was made a criminal offense. ${ }^{68}$

The campaign for the law was a bitter one. All of the old prejudices were raked over by the press and the organizations supporting the law. Exaggerated statements were made of the number of Japanese in the state and no factual data was available to refute them since the 1920 census figures were not yet available. ${ }^{\text {.0 }}$ It was charged that the birth rate of the Japanese was so high that they would eventually replace the white people. ${ }^{60}$ The "low standard of living" of the Japanese, and its alleged eventual effect on the whole society, was effectively used as a scare. ${ }^{61}$ Overshadowing economic objections and the claim of nonassimilability of the aliens and their citizen children - "once a Jap always a Jap"-were stressed continuously. ${ }^{62}$ This propaganda was sufficiently effective to insure the adoption of the initiative act by a vote of 668,438 to $222,086 .^{\circ 3}$

55 Mears, Resiment Orientals on the Amertcan Pactitc Coast (1928); Buell, op. cit. silpra note 37 , at 70 .

56 Supra note 51.

57 This provision was held unconstitutional in Estate of Tetsubumi Yano (1922) $188 \mathrm{Cal} .645,206 \mathrm{Pac}$. 995 as denying equal protection of the laws to the alien and equal privileges and immunities to the ward.

58 Cal. Stats. 1921, p. Ixxxiii.

50 TREAT, op. cit. supra note 27, at 267.

60 Rep. Cal. State Bd. Control, op. cit. supra note 9, at 37. See Hearings on JAPANese IMMUgration Before House CoMmittee on IMmmGration and Naturalization, House of Representatives, 66th Cong. 2d Sess. (1920) pt. 1, at 220, 346.

61 Rep. Cal. State Bd. Control, op. cit. supra note 9, at 103, 110; Buell, op. cit. supra note 37, at 72; see Phelan, Why California Objects to the Japanese Invasion (1921) 93 AnNats 16.

62 HEARINGs, supra note 60 , at $240-244$.

63 TreAT, op. cit. supra note 27 , at 281 . 
The campaign against the Japanese did not stop here, however. The Joint Immigration Committee and its allied organizations continued their relentless campaign for exclusion. The proposal of a 1923 amendment expressly forbidding cropping agreements by Japanese and making escheat retroactive to the date of wrongful acquisition ${ }^{64}$ gave the pressure groups an opportunity to renew the numerous charges agamst the Japanese. They also took their case to Congress. Resolutions favoring exclusion were adopted by the legislature in both 1921 and $1923^{63}$ and a provision generally prohibiting admission into this country of aliens ineligible for citizenship was inserted in the immigration act of $1924 .^{66}$ President Coolidge expressed his regret that the bill contained the provision but nevertheless approved the measure. ${ }^{67} \mathrm{~A}$ representative of the Joint Immigration Committee stated in 1942 that the committee considered itself instrumental in securing the adoption of the exclusion provision. ${ }^{68}$

Japanese agricultural interests declined in the period following the adoption of the exclusion law. California farm land controlled by Japanese dropped from 321,276 acres in 1920 to 191,427 acres in $1930 .^{69}$ The groups in California traditionally opposed to Japanese continued active, however, as guardians of the exclusion clause and as sponsors of additional restrictive legislation. An amendment to the alien land law in 1927 prescribed additional statutory presumptions to facilitate prosecution of escheat proceedings and criminal actions. ${ }^{70}$

64 The proposed amendments became law. Cal. Stats. 1923, p. 1020. The retroactive escheat provision apparently divested the aliens of their common-law power to convey good title at any time prior to escheat proceedings. Cf. Mott v. Cline (1927) $200 \mathrm{Cal}$. $434,253 \mathrm{Pac}$. 718. Its practical effect was to make uncertain all titles to agricultural land since the land might conceivably liave been held after 1923 by a person acting $s u b$ rosa for an ineligihle alien. Presumably to rectify this situation the California legislature recently authorized quiet title actions against the state. Cal. Stats. 1945, p. 2552.

65 Ibid. 1921, p. 2165; ibid. 1923, p. 1657.

6643 STAT. (1924) 162, 8 U.S. C. (1940) § 213 (c).

67 ICHIRASHT, op. cit. supra note 17 , at 309 .

69 Hearings Before Sexect Conomtree Investigating National Defense Migration, House of Representattves, on H. R. 113, 77th Cong. 2d Sess. (1942) 11069.

69 14th Census of the United States: 1920, Agriculture, Vol. II, p. 313; 15th Census of the United States: 1930, Agriculture, Vol. IV, p. 302.

To Cal. Stats. 1927, p. 880 . One presumption created by this amendment (that the defendant was an ineligible ahen if the state proved that he has been in use or occupation of real property and was a member of a race ineligible for citizenship) was upheld in Morrison v. California (1932) 125 Cal. App. 282, 13 P. (2d) 800, appeal dismissed (1933) 288 U.S. 591 . The other presumption (that the defendant in a criminal action was an ineligible alien where the state alleged such ineligibility and proved the acquisition of real property) was held to deny due process in Morrison v. California (1934) 291 U.S. 82 . 
A campaign in the early thirties to repeal the exclusion provision of the immigration act of 1924 was countered by agitation in California involving propaganda in the press contending that oriental competition was sapping the American economy, suits against Japanese merchants for alleged patent infringement, a movement to boycott Japanese-produced commodities, and introduction of legislation to squeeze the Japanese from agriculture entirely. ${ }^{71}$ At the same time, however, the alien land law was apparently not seriously enforced; one observer reported in 1934 that the law was virtually a dead letter in many if not all parts of the state. ${ }^{72}$ This condition continued until shortly after the outbreak of war with Japan in December, $1941 .^{73}$

The historically anti-Japanese forces took advantage of Pearl Harbor to urge the evacuation of all resident Japanese from the west coast, a policy adopted by the military in February, 1942. Mass removal and ultimate deportation were, of course, a logical result of the earlier campaign for exclusion. It became apparent by the end of 1942, however, that the program of the War Relocation Authority for the further resettlement of the evacuees throughout the country would seriously jeopardize the success of any attempt to deport the evacuees or keep them from eventually returning to the west coast. There followed an amazing and vicious campaign, emanating largely " from California, to reactivate west coast prejudice and stir up national feeling against the evacuees. ${ }^{74}$ One by-product of this campaign was a 1943 amendment to the alien land law enacting stricter reporting requirements from ineligible alien guardians, providing criminal penalties for violation of the law (as distinguished from conspiracies to violate it), raising the maximum penalty, and authorizing injunction and declaratory judgment suits as additional enforcement procedures. ${ }^{i 5}$ Another offshoot was a renewed alien land law enforcement program. ${ }^{76}$

After initial successes the campaign failed, chiefly because of

71 McWilliams, Once Again the "Yellow Peril", The Nation, June 26, 1935, at 735; Pajus, op. cit. supra note 20, at 165 .

72 STRONG, op. cit. supra note 9, at 211.

73 See McWirIaMs, Prejudice (1944) 65. The lack of any serious, concerted attempt to enforce the law lends credence to the conclusion that the benefits derived by the anti-Japanese factions from pushing for adoption of ahen land laws "were not dependent upon the actual presence or absence of the Japanese farmers, hut rather upon the process of opposing them." Ibid.

i4 Ibid. 231-273.

75 Cal. Stats. 1943, pp. 2917, 2999.

76 See REP. W. R. A. Jan.-June 1944, at 44. 
WRA's country-wide educational program, the excellent record of relocating evacuees, the excesses of the race-baiters themselves, and the brilliant exploits of the Japanese-American combat team in Italy and France. The west coast was reopened to evacuees in January, $1945 .^{77} \mathrm{~A}$ wave of terrorism in California against returning evacuees arose in the spring but subsided after (if not because) it became apparent that the nation was wholly out of sympathy with such activities and that the inflow of evacuees was continuing. ${ }^{78}$ A rear-guard action in the 1945 session of the legislature, however, resulted in a $\$ 200,000$ appropriation to enforce the alien land law, ${ }^{79}$ and additional amendments designed to remove escheat actions from the operation of any statute of limitations, ${ }^{80}$ to centralize responsibility for supervising enforcement in the attorney general, and to provide an incentive for local enforcement by splitting the proceeds of successful escheat actions with the counties in which the land is situated. ${ }^{81}$

As mentioned previously, there were some fifty actions pending in California to escheat agricultural lands by the early spring of 1946. All of them were against persons of Japanese ancestry. The majority of the suits were centered in the lower San Joaquin Valley, in Fresno and Tulare counties. It had been announced that fifteen additional suits were ready for filing in Fresno county, and that 150 farms in Tulare county were under investigation. ${ }^{82}$ It may be siguificant that most of the reported instances of terrorism in the spring of 1945 occurred in these two counties. ${ }^{83}$

THE SUPREME COURT DECISIONS

The validity of the 1920 alien land law came before the Supreme Court in 1923 in Porterfield v. Webb, ${ }^{84}$ which involved a proposed

77 Pub. Proc. 21, War Dept., Dec. 17, 1944, 10 FEd. REg. (1945) 53; Pub. Proc. WD-2, War Dept., Jan. 20, 1945, 10 FED. REg. (1945) 889.

78 REP. SEC. INT. 1945, at 275.

79 Cal. Stats. 1945, p. 2739.

80 Ibid. p. 2177.

81 Ibid. p. 2164. The proponents of the alien land law suffered a definite setback, however, in the 1946 election. So-called Proposition 15, to validate all legislative amendments subsequent to the 1920 initiative act, was decisively defeated. Pacific Citizen, Nov. 9, 1946, at 1.

82 Ibid. at 2.

${ }^{83}$ Pacific Citizen, Feb. 2, 1946, at 1. Every reported case arising under the California alien land law that the writer has been able to discover involved Japanese, with the exception of several that were not escheat or criminal actions brought by the state. See Mott v. Cline (1927) 200 Cal. 434, 253 Pac. 718; Alfafara v. Fross (1945) 26 Cal. (2d) 358,159 P. (2d) 14.

84 (1923) 263 U.S. 225. 
lease of agricultural land to a Japanese alien. The Court also had before it Terrace $v$. Thompson, ${ }^{85}$ testing the constitutionality of the Washington alien land law which prohibited aliens who had not in good faith declared their intention to become citizens from owning and leasing certain lands, and which likewise involved a lease of agricultural land to a Japanese alien. A decision was handed down first in the Terrace case. Justice Butler, speaking for the Court, concluded that legislation which demed aliens the right to own real property did not violate the due process guaranty for the reason that the Fourteenth Amendment did not divest the states of those police powers reserved at the time of adoption of the Constitution; and that one of those powers, in the absence of a treaty provision to the contrary, was the authority to deny aliens the right to own land within the state. With respect to the equal protection issue, Justice Butler found "real differences" between a declarant and à nondeclarant alien in the renunciation of allegiance to his former country by a declarant alien. He denied that a person who was ineligible for naturalization was discriminated against since "The rule established by Congress on this subject, in and of itself, furnishes a reasonable basis for classification in a state law withholding from aliens the privilege of land ownership", 86 and "If one incapable of citizenship may lease or own real estate, it is within the realm of possibility that every foot of land within the State might pass to the ownership or possession of noncitizens." ${ }^{87} \mathrm{He}$ also distinguished the denial of the right to own or lease land from the right to earn a living in the common occupations on the ground that the "quality and allegiance of those who own, occupy, and use the farm lands within its borders are matters of highest importance and affect the safety and power of the state itself."

In the Porterfield case the Court relied almost entirely upon its analysis in the Terrace decision, stating that the cases were similar and that the Court could not "say that the failure of the California Legislature to extend the prohibited class, so as to include eligible aliens who have failed to declare their intention to become citizens of the United States, was arbitrary or unreasonable." ${ }^{\text {89 }}$

85 (1923) 263 U.S. 197.

86 Ibid. at 220.

8T Ibid.

88 Ibid. at 221.

80263 U.S. at 233. At the same term the Court disposed of two other cases arising under the California law. The prohibition of stock ownership in corporations authorized to own agricultural land was sustained in Frick v. Webb (1923) 263 U. S. 326. In Webb v. O'Brien (1923) 263 U.S. 313, the Court held that a cropping contract gave a Japanese 


\section{Equal Protection.}

The equal protection clause of the Fourteenth Amendment does not, of course, forbid classification for legislative purposes; it only requires that all classifications be based upon substantial differences having a reasonable relation to the objects or persons dealt with and to the public purpose sought to be achieved..$^{90}$ By its very nature this standard is not susceptible of precise definition. Great weight is given to the legislature's appraisal of local conditions, and the usual presumption of constitutionality arises. Nor is it essential that the complete source of the evil sought to be cured be treated by the legislation. ${ }^{91}$ But a classification arbitrary on its face or shown to be arbitrary by evidence or judicially cognizable facts will not be sustained. ${ }^{92}$

It is well established that aliens are entitled to the protection of the Fourteenth Amendment and for this reason the courts have stricken down laws which had the effect of denying aliens the right to engage in the "common occupations". ${ }^{93}$ At the same time the courts have been loathe to invalidate restrictions upon aliens in certain professions or occupations where some special public interest may conceivably be served. ${ }^{21}$ And even prior to the 1923 alien land law decisions the courts consistently assumed that the power of the states to restrict alien land ownership, carried over from the common law, was unaffected by the Fourteenth Amendment. ${ }^{95}$

alien use, control, or benefit of agricultural land that was prohibited, reversing the lower court's decision [(N.D.Cal. 1921) 279 Fed. 117] and in effect refusing to follow the state court's interpretation of the law prior to the 1923 amendment which specifically proscribed cropping contracts [In re Okahara (1923) 191 Cal. 353, 216 Pac. 614].

In the recent Oyama decision, supra note 6 , the California supreme court added nothing to the rationale of the Porterfield decision, except to hold that the "clear and present danger" test applicable to restrictions upon civil hberties was not relevant, and that it was enough if there was (as the court found) a "rational basis" for the classification.

${ }^{90}$ Southern R. Co. v. Greene (1910) 216 U.S. 400; Frost v. Corporation Comm. (1929) 278 U.S. 515; Old Dearborn Co. v. Seagram Corp. (1936) 299 U.S. 183.

91 Clarke v. Deckebach (1927) 274 U.S. 392.

92 Weaver v. Palmer Bros. (1926) 270 U.S. 402.

93 Yick Wo v. Hopkins (1886) 118 U.S. 356 (laundry business); Truax v. Raich (1915) 239 U.S. 33 (restaurant cook); Templar v. State (1902) 131 Mich. 254, 90 N.W. 1058 (barbering); In re Opinion of Justices (1911) 207 Mass. 601, 94 N.E. 558 (hotel and restaurant business); State v. Sinchuk (1921) 96 Conn. 605, 115 Atl. 33 (news dealing).

04 Clarke v. Deckebach, supra note 91 (operation of poolrooms); Trageser v. Gray (1890) $73 \mathrm{Md}$. 250, 20 Atl. 905 (sale of hquor); In re Yamashita (1902) 30 Wash. 234, 70 Pac. 482 (practice of law).

95 Cf. Hauenstein v. Lynham (1879) 100 U. S. 483 ; Phillips v. Moore (1879) 100 U.S. 208; Blythe v. Hinckley (1901) 180 U.S. 333. 
It is exceedingly doubtful whether there is any real social purpose served by restrictive state legislation against aliens as a class, at least in the field of land ownership. The arguments pointing to this conclusion are inextricably intermingled with considerations of due process and are therefore reserved for discussion under that section. Even if it be assumed, however, that the denial of the privilege of land ownership to all aliens does not violate the equal protection guaranty and is a proper exercise of state police power, the California law is subject to inquiry for its discrimination against one class of aliensthose ineligible for citizenship-and its application in practice against one group of aliens within that class, the Japanese.

The first of Justice Butler's justifications for the discrimination against meligible aliens was no more than the fact that Congress had not seen fit to make them eligible for naturalization:

"Two classes of aliens inevitably result from the naturalization laws, - those who may and those who may not become citizens. The rule established by Congress on this subject, in and of itself, furnishes a reasonable basis for classification in a state law withholding from aliens the privilege of land ownership as defined in the act."

This statement assumes that the criteria for state classification are the same as for the particular federal classification. Congressional power to restrict or extend naturalization to designated classes of aliens is plenary. Justice Butler set up the judgment of Congress on a purely political issue- - judgment at that with which many thoughtful persons disagree ${ }^{97}$ - as a ground for deciding a constitutional question involving fundamental rights of persons under state law. He ignored the well-established principle that each statutory classification must be tested in the light of the purpose for which the statute was enacted. Surely some more substantial rationale must be provided than this.

Another justification for the discrimination was that if ineligible aliens could lease or own real estate it was within the "realm of possibility" that noncitizens might acquire "every foot of land" within the state. It would be difficult to find a better example of judicial ostrich-ism. Even at the time of the 1923 decisions, the immigration laws absolutely prohibited the immigration of natives of countries within the so-called "barred zone", including the large East Indies

90 Terrace v. Thompson, supra note 85 , at 220 .

97 E.g., Gordon, The Racial Barrier to American Citizenship (1945) 93 U. of PA. L. Rev. 237; In re Po (1894) 28 N. Y.S. 383, 7 Misc. 471. 
islands, French Indo-China, Siam, India, Persia, Afghamistan, and most of China. ${ }^{98}$ Chinese were separately excluded by the Chinese exclusion acts. ${ }^{99}$ Japanese immigration was severely restricted by the gentlemen's agreement. ${ }^{100}$ The only ineligible aliens whose immigration was not prohibited or severely restricted at that time were Koreans and nonwhites of the Central and South American countries; there is nothing to indicate that they constituted any problem whatever. ${ }^{101}$

Only two of the restricted nationalities-the Chinese and the Japanese-had ever migrated to Califorma in appreciable numbers. The Chinese in California had diminished in number from 132,300 in 1882 to 61,639 in 1920, and even Califorma admitted that they were no menace to the future of the state. ${ }^{102}$ The California Japanese population in 1910 was 41,356-1.74 per cent of the state's population-and 4,502 of this total were American-born. The corresponding figure for 1920 was 71,952-2.1 per cent of the state's populationbut by this time over one-third of the total was American-born; ${ }^{103}$ the ratio of aliens to total population did not increase at all during this period. With respect to agricultural lands, the percentage of California farms controlled by Japanese, aliens and citizens alike, increased only from 2.1 to 4.4 , and the acreage involved in 1920 was merely 1.2 per cent of the state's agricultural land. ${ }^{104}$

The year following the Supreme Court decisions saw the enactment of the immigration act of 1924 generally prohibiting further immigration of aliens ineligible for citizenship. ${ }^{105}$ From 1920 to 1940 the total Japanese population in the state increased only from 71,952 (one-third American citizens) to 93,717 (two-thirds American citizens). ${ }^{106}$ During the same period the percentage of Japanese-controlled farms decreased froin 4.4 to 3.9 , and the acreage involved from 1.2 to $0.7 .^{10 r}$ Since these figures include bona fide holdings by citizens, the proportionate decrease in alien holdings has, of course, been even more marked. It is readily apparent that there is no factual

08 Immigration Act of $1917, \S 3,39$ SтAт. (1917) $875,876,8$ U.S. C. (1940) $\S 136($ (1). 09 Supra note 15.

100 Supra p. 65.

101 Supra p. 69.

102 Ibid.

103 ICEIEASEI, op. cit. supra note 17, at 320 .

104 H. R. ReP. No. 2124, 77th Cong. 2d Sess. (1942) 127.

10543 STAT. (1924) 162,8 U.S. C. (1940) \& 213(c).

106 H. R. REP. No. 2124, 77th Cong. 2d Sess. (1942) 96.

$107 \mathrm{Ibid}$. at 122. 
basis whatever to support a conclusion that it is even within "the realm of possibility" for the land holdings of Japanese aliens in California to increase, much less dominate California agriculture.

No one will disagree with Justice Butler's general assertion that the quality and allegiance of persons who own and occupy lands within a state "are matters of highest importance and affect the safety and power of the State itself." The only additional justification given for separate treatnent of ineligible aliens in this connection, however, is the quotation, without amplification, from the lower court's decision in the Terrace case:

"It is obvious that one who is not a citizen and cannot become one lacks an interest in, and the power to effectually work for the welfare of, the state, and, so lacking, the state may rightfully deny him the right to own and lease real estate within its boundaries." 108

The charge that those who cannot become citizens lack an interest in state welfare is merely a generalization unsupported by facts. The vast majority of ineligible aliens in this country are domiciled here. Their economic security lies in the businesses and occupations in which they have established themselves. They have largely reared their children here, children who by virtue of their birth in this country are United States citizens, and who have attended our schools and whose futures are clearly identified with this country. Clearly these aliens have as much at stake in the economic, social, and political ills .or good fortunes of the state as anyone else, regardless of citizen"ship. ${ }^{109}$ It is simply unrealistic to conjecture that ineligible aliens as a cclass have less interest in the welfare of their communities and their : states than have other aliens simply because they are denied the -privilege of becoming United States citizens.

Nor did Justice Butler choose to elucidate his assertion that : aliens who çannot become citizens lack the power effectually to work for the state. Presumably he meant that they lacked the power to vote and to hold public office. The franchise is a privilege withheld from aliens by the state; lack of power to vote is not a disability in-

“ 108263 U.S. at 220.

109 Compare the following statement by Mr. Justice Black in Ex parte Kawato (1942) 317 U.S. 69, 71, upholding the right of a Japanese enemy alien to sue in the federal courts: "Nothing in this record indicates, and we cannot assume, that he [the petitioner] came to America for any purpose different from that which prompted millions of others to seek our shores-a chance to make his home and work in a free coun$=$ try, governed by just laws, which promise equal protection to all who abide by them." 
herent in their status. ${ }^{110}$ Except with respect to the highest federal offices, the same is true of occupancy of public offices. ${ }^{111}$ Here again, it is a dangerous doctrine to permit political discrimination to justify additional discrimination. Even today residents of the District of Columbia are disfranchised but their disfranchisement could hardly justify denying them the right to own land on the theory that they cannot work for the welfare of the state. With ineligible aliens as well as any other disfranchised group, the potential to work constructively for the state exists despite any state-imposed disability to participate in the affairs of government. Actually the ineligible aliens who migrated to this country have played an important historical role in the development of our resources, and they continue to function as an integral segment of our society. As a class their roots are here. No one would deny that during World War II they contributed to the war effort, directly and indirectly, in as many ways as did their adopted countrymen. Again, it is unrealistic to conclude that categorically they cannot or will not work in the interest of the state simply because of their political disability.

The complete artificiality of Justice Butler's political justification is demonstrated by the discrimination in fayor of aliens who have the opportumity but prefer not to become citizens. The California law permits such aliens to own land under precisely the same conditions as citizens. It is not even necessary that aliens be living in the United States in order to enjoy the right to own California land if they are not of a race ineligible for naturalization. Obviously the reasoning of Justice Butler with respect to lack of interest in and incapability of working for the welfare of the state would, if valid at all, apply even more strongly to aliens who fail or refuse to take advantage of the privilege of naturalization extended to them and aliens who do not even live in this country.

Hardly more need be said to demonstrate the lack of substantive basis for Justice Butler's rationalization to support the California law's discrimination against ineligible aliens as a class: But we should not stop here. The unsavory truth is that the law was aimed solely at the Japanese, and during its spotty history of enforcement was used only to throttle them. It should be further tested for its actual dis-

110 United States v. Wong Kim Ark (1898) 169 U.S. 649; Dorsey v. Brigham (1898) 177 Ill. 250, 52 N. E. 303; see Aylsworth, The Passing of Alien Suffrage (1931) 25 AIr. Por. Scr. REv. 114.

111 Connell v. State (1924) 196 Ind. 421,144 N. E. 882 ; but cf. State ex rel. Off v. Smith (1861) 14 Wis. 539; Opimion of the Justices (1877) 122 Mass. 594. 
crimination against a racial group within the more general category. ${ }^{112}$ All legal restrictions which curtail the civil rights of a single ethnic or racial group are immediately suspect. "Pressing public necessity may sometimes justify the existence of such restrictions; racial antagonism never can." 113

Most of the writings of the times on the "Japanese menace" are totally unreliable. One observer, commenting on the charges made against the Japanese during this period, has said:

"Determined to stop the Japanese immigration, the agitators proceeded to convince a majority of the voters of the Pacific Coast of this necessity and to annoy the Japanese already here so much that they would voluntarily depart for Japan. . . . And so the agitators struck at the Japanese in every possible way. Many of the political leaders among these agitators were experienced in such matters.... Every significant thing about the Japanese, whether favorable or unfavorable, was seized upon and twisted about until it made a suitable weapon for injuring the newcomers. Hence, if they asked less than the going wage, they were threatening the American standard of living; if they demanded better wages, they were avaricious; if they were successful in farming and saved enough to buy their own ranch, they were driving the whites out; if they were unsuccessful they were 'wearing out the land.'

"As an actual fact, the specific charges made against the Japanese have very little significance in themselves. They were merely the smoke pouring up from a bonfire; they gave evidence of a fire and that was about all. This the Japanese and their friends discovered when they attempted to answer the charges with facts. It was as useless to answer the charges as to pour water on smoke."114

The most common cry against the Japanese during the campaign for adoption of the 1920 law was that they would soon acquire all of the agricultural land of the state. Justice Butler accepted this possibility as a justification for the discrimination. The cold fact, conclusively demonstrated earlier in this article, is that Japanese aliens never have controlled more than an infinitesimal acreage of California land. With continued prohibition of or severe restrictions upon Japanse immigration certain, and with the resident aliens, the great

112 Yick Wo v. Hopkins, supra note 93 (enforcement only against Chinese of restrictive laundry ordinance purporting to be of general applicability held to be denial of equal protection); see also Quong Wing v. Kirkendall (1912) 223 U.S. 59.

113 Korematsu v. United States, supra note 7, at 216.

114 Strong, op. cit. supra note 9, at 125. See also War Relocation AuthortTy, Myths and Facts About the Japanese Americans (1945). 
majority of whom came here before 1924, rapidly dying off, the next few decades will see the percentage of alien holdings approach zero.

Another charge, more relevant to the public interest, if true, than the mere quantity of land controlled by the Japanese, was that the Japanese were destroying the productivity of the soil more than were other races of aliens. No reliable factual support for the assertion has been found. To the contrary, there is evidence that they were excellent farmers and preserved the soil.

"The complaint that the Japanese 'skin' the land and ruin the orchards is frequently heard. Most of the Japanese are tenants, and tenant farming is likely to have such results. No case can be made against the Japanese as against other tenants, however. On the contrary, while one finds rather numerous instances in which the landowners have been dissatisfied with the Japanese tenants they have had, the general opimion is that the Japanese are good farmers and give rather more than less interest than is usual among tenants to the care and conservation of the properties leased by them. At Sacramento recently the president of one large fruit-shipping firm and the treasurer of another said that the Japanese were among the most careful and painstaking orchardists. At Fresno, a prominent Armemian told me that he would rather lease his vineyards to Japanese than to farmers of his own race because they took better care of them. The charge that the Japanese ruin the farms is a charge, which, like many others, one hears less of the closer he gets to the place where the damage is presumed to have taken place. On the whole the Japanese are regarded as good farmers and good tenants." 11s

It was charged that the Japanese drove "white" farmers from the soil by their long hours of work and low standards of living, that the "white" farmer could not maintain his usual standard of living and compete with the Japanese. Even assuming the truth of this charge, it is anomalous that efficiency and productive ability should ever be a valid ground for discrimination against any group. The charge was nevertheless largely false.

Writing in 1924, Robert Welles Ritchie said:

"The three areas of greatest Japanese concentration then, in 1920, as now, were in the cantaloupe and winter-lettuce fields of the Imperial Valley, in the extreme southeastern part of the state; in the mountain fruit center of Placer County; and in the strawberry fields and the potato, celery, onion and asparagus districts roughly embraced in the term, the Delta, which lies in the exact center of the state. Let us be very blunt in this context and say that in the Imperial Valley and the 
Delta country the Japanese never displaced white men, for white men would not work there; and in the mountain fruit district the Chinese, and after them the Japanese, came in-after nearly every white man had quit-and made a go of a crippled industry."110

Other sources bear out this conclusion. ${ }^{117}$ The Japanese turned primarily to intensive farming, which required painstaking care and long, hard hours of toil, and in which the ordinary American farmer was slow to engage. ${ }^{118}$ By and large they created their own niche in California agriculture without replacing white farmers to any great extent. In so doing they contributed greatly to the development of the agricultural wealth of the state.

Admittedly the standard of living of the Japanese was at first low. The living standard of any people is determined mainly by opportunities to make a decent living. There is ample evidence that the Japanese were constantly striving to overcome the handicaps that forced them, when they first arrived as immigrants, to accept low wages or starve. ${ }^{119}$ They were no different from any other first-generation group in that they of necessity worked hard and long hours to get their foothold. As their economic status improved, their living standards rose. The natural effect of the alien land law was to restrict their opportunities to better themselves.

The remaining charges made against the Japanese relate to alleged cultural and political allegiance to Japan and inability to be assimilated in this country, telescoped in the charge "Once a Jap always a Jap". General De Witt grasped at them in his post-mortem justification for the west coast evacuation of the Japanese in 1942; Mr. Justice Murphy summarizes them in his dissent in the Korematsu decision as follows:

"Individuals of Japanese ancestry are condemned because they are said to be 'a large, unassimilated, tightly knit racial group, bound to an enemy nation by strong ties of race, culture, custom and religion.' They are claimed to be given to 'emperor worshipping ceremonies' and to 'dual citizenship.' Japanese language schools and allegedly pro-Japanese organizations are cited as evidence of possible group disloyalty, together with facts as to certain persons being educated and residing at length in Japan. It is intimated that many of these

116 The Country Gentleman, March 1, 1924, p. 1.

117 See Mrilis, op. cit. supra note 35, at 145; 23 Rep. IMang. CoMn. (1911) 86.

118 MnIIs, op. cit. supra note 35 , at 89 .

119 Ibid. at 164; H. R. Rep. No. 2124, 77th Cong. 2d Sess. (1942) 64; Patmer, ORIENTAIS IN AMERICAN LIFE (1934) 55. 
individuals deliberately resided 'adjacent to strategic points,' thus enabling them 'to carry into execution a tremendous program of sabotage on a mass scale should any considerable number of them have been inclined to do so." "120

It would follow from these charges, particularly if there were any factual basis for the assertion that the Japanese were rapidly gaining control of all the agricultural lands in the state, that in time of international crisis the Japanese might constitute a special hazard to the security of the state. The argument might then be made that the state, while prohibited by treaty from dealing with all sources of the evil, could nevertheless minimize the danger by striking at the ownership of agricultural land.

Accepting for the moment the premise that the Japanese aliens might have constituted a special risk, and the implicit assumption as to the inadequacy of the federal war power, the argument is unsound. Prohibition of ownership of agricultural land by aliens inevitably increases the likelihood of their gravitation to other better income opportunities, which could be found only in urban areas. Under conditions of modern warfare the greater danger to internal security from espionage and sabotage is found in the city. Urban centers provide the factories necessary for war production, the warehouses, the heart of the transportation and communication systems, the concentration of vital information needed by the enemy. And surveillance of enemy agents' activities is infinitely more difficult among tightlypacked masses of humanity than it is in sparsely settled rural areas. If there was any real danger from the resident Japanese in California, the alien land law tended to increase it by driving them from the farms.

But like the other accusations leveled against the Japanese, these charges were also a mass of misrepresentations, distortions, and exaggerations. Mr. Justice Murphy was clearly correct in his conclusion that every charge "relative to race, religion, culture, geographical location, and legal and economic status has been substantially discredited by independent studies made by experts in these matters."12I We have just finished a bitter struggle with Japan that put the observations of these experts to the test. It is reported that no case of espionage or sabotage by any person of Japanese ancestry domiciled in Hawaii or on the nainland was uncovered during the entire course

120 Korematsu v. United States, supra note 7, at 237.

121 Ibid. at 240. See also, WAR RELOCATION AUTHORITY, loc. cit. supra note 114. 
of the war. Thousands of the aliens in the relocation centers streamed out to plant and harvest sugar beets and other vital war crops. Many others found maintenance jobs on railroads, employment at ordnance depots, positions in military language schools and war agencies, and other war-connected service. Probably no better proof of the assimilation of the Japanese exists than the record of the 23,000 JapaneseAmerican lads, the sons of the aliens so vilified by the race-baiters, who fought brilliantly in both the European and Pacific war theaters. The simple truth is that the vast majority of the Japanese in this country are bound to us by the most powerful economic, family, and personal considerations. Discrimination against them in the ownership of land on the basis of inability to be assimilated or because of closer ties to the motherland than other groups of immigrants is unwarranted.

\section{Due Process.}

In the Terrace decision it was concluded that legislation denying aliens the right to acquire real property did not violate the due process guaranty for the reasons that: (1) the Fourteenth Amendment did not take away from the states those police powers that were reserved at the time of the adoption of the Constitution; and (2) one of those powers, in the absence of any treaty provision to the contrary, was to deny aliens the right to own land. Admittedly the Fourteenth Amendment did not deprive the states of the power to safeguard the public health, safety, and welfare. And at common law an alien's rights in real property were, generally speaking, subject to forfeiture to the sovereigu. ${ }^{122}$ Nevertheless, a control sanctioned by the common law does not forever remain inviolate. What may once have been thought to be a reasonable restriction in the common interest may by changing circumstances or upon reexamination be shorn of its social justification. ${ }^{123}$ And the due process clause of the Fourteenth Amendment is operative to protect the individual, whether he be alien or citizen, against state interference with private rights that cannot be more

${ }^{122}$ An alien could acquire real property by act of the parties, although not by operation of law. In the case of leases of houses by merchants who were alien friends, their rights were apparently indefeasible. In all other instances they held subject to the possibility of forfeiture to the sovereign. Co. LITT. *2.b; 1 BL. Consa. *371; Fairfax v. Hunter's Lessee (1813) 11 U. S. 602; Dutton v. Donahue (1932) 44 Wyo. 52, 8 P. (2d) 90.

123 Compare cases relating to the effect of changed circumstances on constitutionality of statutes, e.g., Nashville C. \& St. L. Ry. Co. v. Walters (1935) 294 U.S. 405 ; Chastleton Corp. v. Sinclair (1924) 264 U. S. 543. 
than offset by public benefit. This balance of convenience is the heart of the due process issue. Justice Butler disposed of it by ignoring it.

What public benefit is served by state restrictions on alien land ownership? The justification at common law rested primarily upon the security of the realm. ${ }^{124}$ But under our federal system the responsibility for security against attack or infiltration by foreign nations rests primarily in the federal government. Congress has plenary power over immigration. ${ }^{125}$ All aliens may be and are required to register themselves as such. ${ }^{126}$ Persons acting on behalf of other countries must similarly register, and copies of any political propaganda such persons disseminate must be filed with the government. ${ }^{127}$ On outbreak of war enemy aliens are subject to summary apprehension and internment; ${ }^{12 S}$ persons can be evacuated fron critical defense areas regardless of citizenship where the federal government deems it a military necessity and there is a rational basis for that judgment; ${ }^{120}$ curfew may be imposed as a precautionary measure under similar conditions. ${ }^{130}$ Or where the need is imperative, martial law can be established..$^{131}$ In addition to these restraints, sunmary federal seizure or other control of alien assets, real property as well as tangible and intangible personalty, that might conceivably be utilized against the best interests of the country is fully authorized in tine of energency. ${ }^{132}$

The potential security hazard created by our alien residents can, for that matter, easily be overexaggerated. Aliens constitute but a snall fraction of our population, and their number is decreasing. ${ }^{133}$ Severe quantitative and qualitative restrictions upon immigration preclude any substantial threat from new immigrants. ${ }^{134}$ More int-

124 See Calvin's Case (1609) 77 Eng. Rep. 377.

125 Fok Yung Yo v. United States (1902) 185 U.S. 296.

1268 U.S. C. (1940) § 452 ; Hines v. Davidowitz (1941) 312 U.S. 52.

12 T 22 U.S. C. $(1940) \S 611$.

12850 U. S. C. $(1940) \$ 21$.

120 Korematsu v. United States, supra note 7.

130 Hirabayashi v. United States (1943) 320 U.S. 81.

131 See Fairman, The Law of Martial Rule and the National Emergency (1942) 55 HARv. I. REv. 1253.

13250 U. S. C. App. Supp. V. (1946) §§ 1-31, 616. For discussion, see Enemy Property (1945) II Law \& Contramp. Prob. 1 et seq.

133 The 1940 alien registration disclosed 4,889,770 aliens in this country, 3.7 per cent of our then total population of $131,669,275$. (Information received froin Bureau of the Census.) In 1920 the alien population was $7,430,809$, and in 1930 it was $6,284,613$. See Fellman, The Alien's Right to Work (1938) 22 MINN. L. REv. 137.

134 The total annual immigration quota, computed under the immigration act of 1924 , as amended [8 U.S. C. (1940) $\$ 211$ ], is now 153,879 , or sligltly over 0.1 per cent 
portant, this country has always been an in-migrant nation, and the great bulk of the immigrants have taken root here. By and large their interests have merged with the interests of the American people. ${ }^{135}$

The lack of need for state controls on alien land ownership as a security measure is strongly indicated by the action taken by New Jersey and New York during World War II. In 1943 New Jersey, which had previously limited to alien friends the right to hold real property, placed resident enemy aliens in the same category as alien friends if they were not interned, their property had not been confiscated, and they were permitted to do business by the federal government. ${ }^{136}$ In 1944 New York, upon recommendation of the law revision commission, conferred upon all aliens the same rights to hold land as native-born citizens, a privilege theretofore reserved to nonenemy aliens. It was pointed out in a footnote to this amendment that control over enemy alien property was left solely to the federal government, "which has already acted for the protection of the nation through the Trading with the Enemy Act and various proclamations and executive orders." 137

What other legitimate justifications there could be for restrictions upon alien land ownership are difficult to conceive. Aliens have no inherent special privileges if permitted to own land. Like citizens they must pay taxes ${ }^{138}$ and obey all applicable laws. ${ }^{130}$ There is nothing inherently injurious to morals or dangerous to the public health or safety in the mere fact of land ownership or control; the cases upholding discrimination against aliens in the right to engage in certain

of our 1940 population. The quota has never been filled in recent years, and the net inflow has been considerably reduced by emigration. Thus, from 1931 to 1936 there was a net emigration of 103,142 . Fellman, loc. cit. supra note 133 . During the following three years the total net immigration was 149,958 , less than one year's quota. Note (1940) 17 N. Y. U. L. Q. 242, 253. In the pre-war years of 1940 and 1941 net immigration figures were 48,295 and 34,661 , respectively. (Statistics furnished by Immigration and Naturalization Service.)

Qualitative requirements are strict. The law excludes, among others, persons mentally or physieally defective, paupers or others likely to become a public charge, felons, immoral persons, contract laborers, and persons believing in or affiliated with organizations that believe in forcible overthrow of the government. 8 U.S. C. (1940) $\& 136$.

135 For judicial recognition of this fact, see the quotation from Ex parte Kawato, supra note 109.

136 N. J. Laws 1943, p. 395.

${ }^{137}$ N. Y. Laws 1944, p. 627.

138 They are entitled to equal taxation, however. Ex parte Kotta (1921) 187 Cal. 27, 200 Pac. 957.

139 Carlisle v. United States (1872) 83 U.S. 147. 
occupations that may be specially affected with a public interest ${ }^{140}$ have no application here. On the contrary, by bringing aliens into closer contact with our institutions and giving them a stronger economic interest in the public well-being, alien land ownership appears to be socially desirable.

If anything, restrictive land laws would seem to affect the public mterest adversely. By narrowing economic opportunities they limit full utilization of the natural capacities of the aliens to contribute to the development of economic wealth. By the very fact of overt discrimination they tend to breed distrust and disillusionment and to retard assimilation. At the same time they tend to prostitute the naturalization process by makmg the economic motive a primary incentive for seeking American citizenship.

In eighteen states aliens are expressly authorized by statute or constitutional provision to acquire and dispose of real property as if they were citizens. ${ }^{141}$ Aliens who establish residence in the state have the same rights in six additional jurisdictions. ${ }^{142}$ It is hardly credible that any real public purpose is served by restrictions on alien land ownership when half the states have seen fit to confer upon all aliens

140 Cases cited supra note 94.

141 AIA. Const. art. I, \$ 34; ALA. Code (1940) tit. 47, § I; Colo. Const. art. II, § 27; Colo. Stat. (1935) c. 7, § 6; Conn. Gen. Stat. (1930) §\$ 5055-5056; Dex. Rev. Code (1935) $\$ \S 3655-3657$; FLA. Const., Declaration of Rights, $\$ 18$; FLA. STAT. (1941) \$ 731.28; Me. Rev. Stat. (1944) c. 154, § 2; Mass. Laws (1932) c. 184, \$1; Mich. Const. art. XVI, $\$ 9$; Mrce. CoMrP. Laws (1929) \$13493; Nev. CoMP. Laws (1929) $\S 6365$; New York Laws 1944, p. 627; N. C. GeN. Stat. (1943) § 64-1; N. D. REv. CodE $\S \S 47-0111,56-0116$; OHIO CODE (Throckmorton, 1940) \$10503-13; R. I. GEN. LAWS (1938) c. 432 ; S. D. Const. art. VI, § 14; S. D. Code (1939) \$\$ 51.0205, 56.0120; TENN. CODE (Williams, 1934) $\$ \$ 7187-7190 ;$ W. VA. Const. art. II, $\$ 5$; W. VA. CoDE (1943) § 3541; WIs. Const. art. I, § 15; WIs. STAT. (1943) §§ 234.22, 234.23.

Alaska and Hawaii permit unrestricted land ownership by aliens resident in the United States [8 U.S. C. (1940) $\$ \S 71-77]$ and Georgia, Maryland, and New Jersey by alien friends [GA. CODE (1933) §§ 79-303, 79-304; MD. CoDE (Flack 1939) art. 3, § 1; N. J. REv. Stat. (1937) $\$ \S 3: 3-13,46: 3-18]$. There are only acreage limitations in Indiana, Minnesota, Pennsylvania, and South Carolina [INo. Stat. ANN. (Baldwin, 1934) $\$ \S 14707,14708$; MnnN. Stat. (1941) §500.22; PA. Stat. (Purdon, 1936) tit. 68, $\$ \$ 22-32$; S. C. Const. art. III, § 35; S. C. CoDE (1942) \$\$ 8687, 8907, 8908, 7790].

142 Arkansas, Iowa, Mississippi, New Hampshire, Oklahoma, and Wyoming. ARx. Const. art. I, § 20; Iowa Const. art. I, § 22; IOWA Code (1939) §§ 10214, 10215; MIss. Code (1942) § 842; N. H. Rev. LAws (1942) c. 259, § 19, c. 340, §9; OKLA. Const. art. XXII, § 1; OrLa. Stat. (1941) tit. 60, §§ 121-127; Wro. Const. art. I, § 29; Wro. REv. STar. (1931) §88-4004. Recently enacted Arkansas and Wyoming statutes prohibiting land ownership by persons of Japanese descent and by ineligible ahens, respectively (Ark. Laws 1943, p. 74; Wyo. Laws 1943, p. 33) clearly run afoul state constitutional provisions guaranteeing ahien residents equal rights with citizens in land ownership. See Applegate v. Luke (1927) 173 Ark. 93, 291 S. W. 978. 
or upon resident aliens the same rights as citizens, states ranging from hinterland agricultural states with negligible alien populations, such as Arkansas and Iowa, to heavily industrialized and urbanized states like Massachusetts and New York with large alien concentrations. ${ }^{143}$

Balanced against the dubious need for state alien land restrictions of any kind is the interference with private rights that flows from the California law. An agricultural landowner is denied the right to sell land to or avail himself of the services of a Japanese alien except as employer, with consequent master-servant liability; he must pay cash for the alien's services and cannot share the risk through share-cropping arrangements. The alien is prohibited from advancing beyond the status of an ordinary laborer in one of this country's major occupations. He cannot utilize his skill or his savings to better himself economically in what is often the one field of endeavor he knows. If either the landowner or the alien violates the law, he is subject to criminal prosecution, and the alien's interests are subject to escheat as of the date of acquisition, thus rendering the alien accountable for any interim profits. This is in sharp contrast with the comparatively liberal common-law provisions which attached no criminal penalty to alien ownership and permitted the alien to acquire and enjoy land until forfeiture proceedings were instituted. These are substantial invasions of private rights; no court should uphold them in the absence of positive evidence of a corresponding public benefit. The writer believes the conclusion to be inescapable that no such benefit can be shown.

Furtherniore, because the 1911 treaty with Japan was terminated in January, 1940, ${ }^{144}$ the California law night now deny Japanese aliens the right to own or lease residential and commercial property as well as agricultural land. This depends upon whether the provision authorizing acquisition of land by ineligible aliens only to the extent provided by "any treaty now existing" is construed to incorporate the 1911 treaty in the law, irrespective of subsequent changes in or abrogation of the treaty. The state attorney general has taken the position that the treaty was incorporated in the law, citing usual rules of statu-

143 In 1940 the percentage of aliens (including persons wliose citizenship was not ascertained by census enumerators) in these four states, in the order named was 0.15 , 1.2, 8.2 and 8.2. (Computed from statistics in 16th Census of the United States: 1940, Population, Vol. III.)

144 H. R. Doc. No. 339, 78th Cong. 1st Sess. (1943) vol. II, p. 189. 
tory construction; ${ }^{\mathbf{1 4 5}}$ a superior court which had taken the contrary view, and held that the law is now applicable to commercial leases, was reversed on appeal, ${ }^{146}$ but the California supreme court has not yet ruled on the issue. It is clear that the Washington statute upheld $\mathrm{m}$ the Terrace decision now cuts practically a clean sweep with respect to Japanese aliens. ${ }^{14 \tau}$ The absurdity of the doctrine casually enunciated in the 1923 land law decisions-that state power to prohibit alien land ownership is limited only by treaty provisions-could hardly be better illustrated. If the Japanese alien evacuees returning to their domiciles are by law prohibited from purchasing or leasing any real property whatever, those not fortunate enough to have acquired business properties before abrogation of the treaty-and to have retained them through all the vicissitudes of evacuation-are relegated to the position of wage earners. In effect the law would deny them the right to engage in any common occupation which in ordinary business practice requires the ownership or lease of real property. ${ }^{148}$ Similarly-and this is even more fundamental-those without homes to return to would be unable to buy or lease houses in which to live. ${ }^{149}$ It is imconceivable that any court should hold that such a harsh and repressive law did not deprive aliens of due process of law.

$$
* * * * *
$$

The California Alien Land Law is a symbol of racial intolerance and prejudice. Its genesis and history are part and parcel of the whole sordid spectacle of anti-Japanese agitation in California. In such a context it should not be enough to indulge in speculative justifications of the law as the Supreme Court did in 1923 or to plead ignorance of local conditions and the "possibility" of a "rational basis" for the legislative judgment. ${ }^{150}$ Restrictive legislation stemming from race

1453 Op. ATr'y GEN. (1944) 112. And of. In re Heath (1892) 144 U.S. 92 ; In re McNabb (D. Ore. 1909) 175 Fed. 511; Fischer v. Simon (1902) 95 Tex. 234, 66 S. W. $447,882$.

146 Palermo v. Stockton Theatres, Inc. (1946) 76 A. C. A. 26, 36, 172 P. (2d) 103, 109, hearing granted (Oct. 31, 1946).

147 The Washington law excepts only mineral lands and lands necessary for their development or manufacture of products tberefrom. See WASH. REv. StaT. (Remington, 1933) $\$ \$ 10581,10582$.

$148 \mathrm{Cf}$. cases cited supra note 93.

149 While a license to use a louse might not be forbidden since it constitutes no interest in land, the likelihood of finding landlords willing to grant revocable licenses is exceedingly remote. For all practical purposes the alien's right to live in the state would be meaningless.

150 Cf. Clarke v. Deckebach, supra note 91; People v. Oyaina, supra note 6. 
prejudice, particularly against a minority that is unable to participate in the political process, calls for a more searching judicial inquiry. ${ }^{161}$ Such an inquiry would reveal, it is submitted, that the alien land law is unjust and unjustifiable legislation, and that it clearly violates rights protected by the Fourteenth Amendment.

151 See United States v. Carolene Products Co. (1938) 304 U.S. 144, 152, n. 4; cf. Nixon v. Herndon (1927) 273 U.S. 536; Smith v. Texas (1940) 311 U.S. 128; Korematsu v. Umited States, supra note 7. 